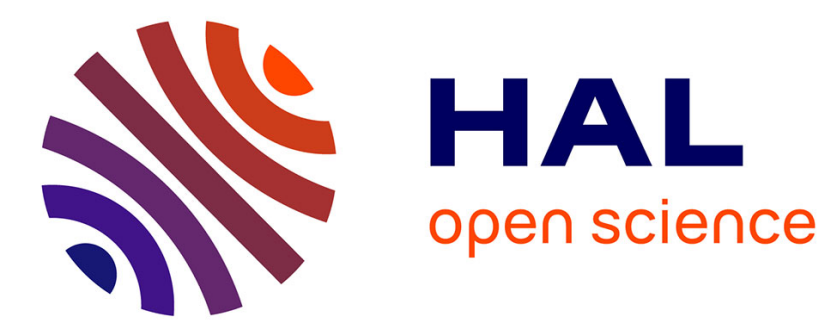

\title{
Neuronal expression of brain derived neurotrophic factor in the injured telencephalon of adult zebrafish
}

Pietro Cacialli, Livia d'Angelo, Olivier Kah, Pascal Coumailleau, Marie-Madeleine Gueguen, Elisabeth Pellegrini, Carla Lucini

\section{To cite this version:}

Pietro Cacialli, Livia d'Angelo, Olivier Kah, Pascal Coumailleau, Marie-Madeleine Gueguen, et al.. Neuronal expression of brain derived neurotrophic factor in the injured telencephalon of adult zebrafish. Journal of Comparative Neurology, 2018, 526 (4), pp.569-582. 10.1002/cne.24352 . hal-01699217

\section{HAL Id: hal-01699217 https://hal-univ-rennes1.archives-ouvertes.fr/hal-01699217}

Submitted on 2 Mar 2018

HAL is a multi-disciplinary open access archive for the deposit and dissemination of scientific research documents, whether they are published or not. The documents may come from teaching and research institutions in France or abroad, or from public or private research centers.
L'archive ouverte pluridisciplinaire HAL, est destinée au dépôt et à la diffusion de documents scientifiques de niveau recherche, publiés ou non, émanant des établissements d'enseignement et de recherche français ou étrangers, des laboratoires publics ou privés. 


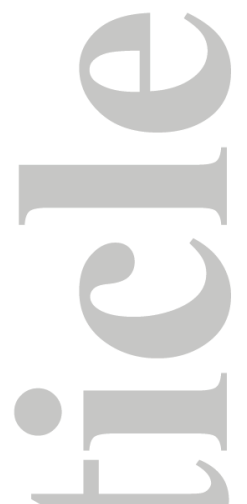

Neuronal expression of Brain Derived NeurotrophicFactor in the injured telencephalon of adult zebrafish

Pietro Cacialli ${ }^{1,2}$, Livia D-Angelo ${ }^{1}$, Olivier $\mathrm{Kah}^{2}{ }^{2}$, Pascal Coumailleau ${ }^{2}$, Marie-Madeleine Gueguen ${ }^{2}$, Elisabeth Pellegrini ${ }^{2 *}$, Carla Lucini ${ }^{1 *}$.

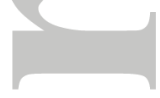

${ }^{1}$ Dpt. Veterinary Medicine and Animal Productions, University of Naples Federico II, Italy

${ }^{2}$ Inserm, UMR 1085, Research Institute in Health, Environment and Occupation, SFR Biosit, University of Rennes 1, Rennes, France

*corresponding authors

Address for correspondence:

carla.lucini@unina.it

elisabeth.pellegrini@univ-rennes1.fr

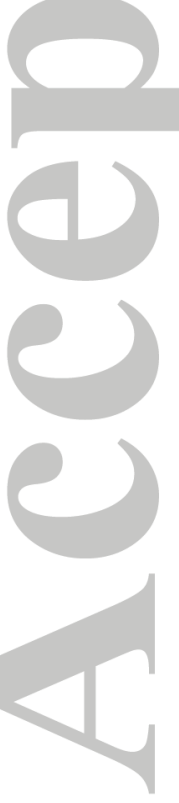




\section{$\underline{\text { ABSTRACT }}$}

The reparative ability of the central nervous system varies widely in the animal kingdom. In the mammalian brain, the regenerative mechanisms are very limited and newly formed neurons do not survive longer, probably due to a non-suitable local environment. On the opposite, fish can repair the brain after injury, with fast and complete recovery of damaged area. The brain of zebrafish, a teleost fish widely used as vertebrate model, also possesses high regenerative properties after injury. Taking advantage of this relevant model, the aim of the present study was to investigate the role of Brain-derived neurotrophic factor (BDNF) in the regenerative ability of adult brain, after stab wound telencephalic injury. BDNF is involved in many brain functions and plays key roles in the repair process after traumatic brain lesions. It has been reported that BDNF strengthens the proliferative activity of neuronal precursor cells, facilitates the neuronal migration toward injured areas, and shows survival properties due to its anti-apoptotic effects. BDNF mRNA levels, assessed by quantitative PCR and in situ hybridization at 1, 4, 7 and 15 days after the lesion, were increased in the damaged telencephalon, mostly suddenly after the lesion. Double staining using in situ hybridization and immunocytochemistry revealed that BDNF mRNA was restricted to cells identified as mature neurons. BDNF mRNA expressing neurons mostly increased in the area around the lesion, showing a peak 1 day after the lesion. Taken together, these results highlight the role of BDNF in brain repair processes and reinforce the value of zebrafish for the study of regenerative neurogenesis.

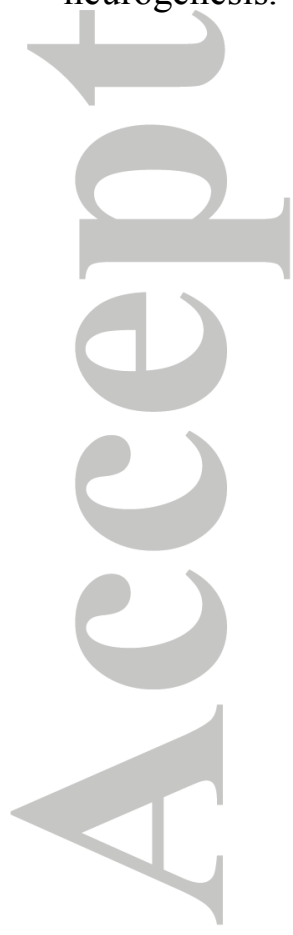




\section{INTRODUCTION}

It is largely known that reparative mechanisms in mammalian brain are very limited, and newly formed neurons do not survive for long time, probably due to a non-suitable local environment. The injury to the brain generates damage to neurons, glia and vascular structures. Secondary damages may be due to glial proliferation leading to scar, which may function as mechanical and biochemical barriers preventing growth of new cells, and lead to axons necrosis and inflammation

(for a review see Kyritsis et al 2014). On the opposite, the brain of adult fish have a high regenerative properties after brain injury, with fast and complete recovery of damaged area, without glial scar formation, and several studies indicated that inflammatory signals can have positive influence on the regenerative response in the brain of zebrafish (for a review see Kyritsis et al 2014). The striking differences in regenerative properties between mammalian and fish brain have been long ascribed to remarkable different adult neurogenesis processes (for a review see Alunni and Bally-Cuif 2016). In mammalian brain only two neurogenic regions are well described: the subventricular zone of the lateral ventricle and the subgranular zone of the dentate gyrus in the hippocampus. In fish, neurogenesis continues along the entire adult life in numerous stem cell niches identified in various/many brain sub-divisions and mostly lining the ventricles, from which newly differentiated neurons start to migrate. Thus, studies on brain regenerative mechanisms in fish have been the subject of numerous researches, due to their potential for the development of new therapeutic approaches (Pellegrini et al 2014; Skaggs et al 2014; Diotel et al 2013; Zupanc 2011).

Brain-derived neurotrophic factor (BDNF) is a member of neurotrophin (NT) family. NTs comprise, in addition to BDNF, the nerve growth factor (NGF), NT-3, NT-4/5, NT 6/7. The binding to three distinct tyrosine kinase receptors (Trk) A, B and C mediates their activities concerning neuronal proliferation, survival, differentiation and plasticity in many neuronal populations of central and peripheral nervous system (Reichardt 2006). However, all NTs also bind with low affinity to the common $\mathrm{p} 75$ receptor.

In the brain, BDNF plays multiple and important roles. An indirect evidence is given by a common single-nucleotide polymorphism in the human BDNF gene, resulting in a valine to methionine substitution in the prodomain (Val66Met), which has been shown to lead to memory impairment and susceptibility to neuropsychiatric disorders (Bath and Lee 2006). In schizophrenia, patients showed in brain tissue reduced BDNF mRNA serum levels (Wysokinski et al 2016). In depressed patients BDNF levels appeared lower, and treatment with antidepressants increased serum BDNF levels compared to controls (for a review see Molendijk et al 2014). During human normal ageing, BDNF plasma levels significantly decreased. In animal models, BDNF content was 
unchanged or increased in the hippocampus of aged Sprague Dawley or Wistar rats, although its receptors levels were decreased, thus certainly resulting in a weaker BDNF action (Silhol et al 2005).

BDNF has also beneficial effects. In Alzheimer disease, in vitro and in vivo studies in rats indicated that BDNF has neuronal protective effects against neurotoxicity caused by amyloid $\beta$ peptide accumulation. In fact BDNF could act as an antioxidative factor since it is known that it increases the level of activity of some antioxidant enzymes (for a review see Tapia-Arancibia et al 2008). Finally, in the treatment of multiple sclerosis, BDNF plays a role in mechanism of remyelination (Korshid Ahmad et al 2016).

In experimental traumatic brain injury (TBI) performed in rodents, BDNF protein expression is modified (Yang et al 1996; Hicks et al 1997, 1999; Griesbach et al 2002; Rostami et al 2014), also in regions far from the injury site (Griesbach et al 2002). Additionally, the mRNA expression of full length and truncated TrkB and $\mathrm{p} 75$ receptors resulted increased after the acute phase of experimental injury (Rostami et al 2014). After TBI, BDNF appears to mediate some beneficial treatments, such as: a) simvastatin administration, which induces BDNF upregulation, promotes neurogenesis in the dentate gyrus of the hippocampus, thereby leading to the restoration of cognitive function in rats (Wu et al 2008); b) transcranial low-level laser light therapy to the brain, partly mediated by stimulation of BDNF in the dentate gyrus of the hippocampus and the subventricular zone, seems to encourage synaptogenesis (Xuan et al 2015); c) exercise, which upregulates BDNF within the hippocampus, is associated with an enhancement of cognitive recovery both in human and rodents (Griesbach et al 2004, 2009). Furthermore, in another kind of no-TBI injury models, such as neonatal rats with left artery ligation to mimic hypoxic-ischemic (HI) encephalopathy, the levels of BDNF increased significantly after hypoxic-ischemic event (Wang et al 2013).

In the present study, we intend to investigate the involvement of BDNF in the telencephalon of adult zebrafish, upon traumatic injury. As previously described for fish species, zebrafish, a teleost fish widely used as model for genetic developmental studies (for a review, see D'Angelo et al., 2016), possesses high regenerative properties of the central nervous system (for a review see Gemberling et al 2013). Profound stab on encephalon (Marz et al., 2011; Kishimoto et al., 2012; Baumgart et al., 2012) and the complete resection of spinal cord (Becker et al., 2008; Vajn et al 2013) are fast repaired with full recovery of locomotion and normal behavior. The high regenerative properties of zebrafish brain can be correlated to the intense adult neurogenesis, mainly localized in 16 neurogenic niches (Grandel et al., 2006; Pellegrini et al., 2007). The dorsal telencephalon comprises the most studied neuronal stem cell niches (Grandel et al., 2006; Adolf et al., 2006; März 
et al., 2011; Kishimoto et al., 2012), and the dorso-lateral zone is retained to be equivalent to the medial pallium (hippocampus) of mammals (Salas et al. 2003; Broglio et al. 2005), which contains one of the two constitutive neurogenic niches of mammals: the subgranular zone of the dentate gyrus (for a review see Migaud et al 2016). BDNF was previously identified in the developing and adult brain of zebrafish (Lum et al., 2001; De Felice et al., 2014; Cacialli et al., 2016; Gatta et al., 2016), as well as in other teleost fish, such as Cichlasoma dimerus (Vissio et al. 2008), European eel (Dalton et al 2009), african turquoise killifish (D'Angelo et al 2014). In the European eel, BDNF expression was reported in the brainstem-spinal cord regenerating model (Dalton et al 2009). However, to our knowledge, the role of BDNF in the telencephalic regenerative processes was not investigated in the telencephalon of zebrafish.

Therefore, to clarify the role of BDNF in repairing mechanisms, we performed stab wound in the dorso-lateral telencephalon of zebrafish, the teleost area equivalent to the hippocampus of mammals, in order to mimic the cellular phenomena of TBI during adulthood. In particular, we investigated BDNF mRNA level upon injury, and identified BDNF expressing cells.

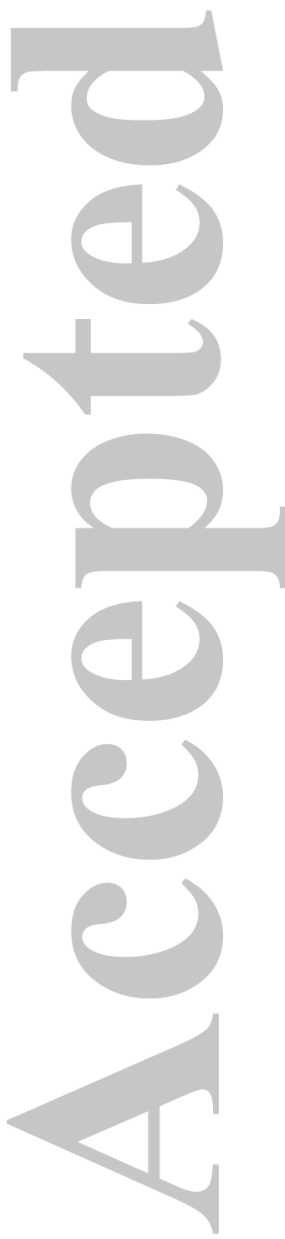




\section{MATERIALS AND METHODS}

\section{Animal and ethics}

All experiments were performed in adult male zebrafish (4 to 6 month-old) housed in the facility (INRA LPGP, BIOSIT, Rennes, France, agreement number: B35-238-6) under standard conditions of photoperiod (14 hours light and 10 hours dark) and temperature $\left(28{ }^{\circ} \mathrm{C}\right)$. Animals were handled and euthanized in agreement with the French regulation concerning the use and protection of experimental animals. This study was approved by the local ethic committee CREEA (Comité Rennais d'Ethique en matière d'Expérimentation Animale, Rennes, France) under the permit number EEA B-35-040.

\section{Telencephalic lesion}

The model of mechanical injuries of the telencephalon was previously developed by Diotel and colleagues (2013). Briefly, adult male zebrafish were anesthetized with tricaine methanesulfonate (MS-222, $50 \mathrm{mg} / \mathrm{ml}$ ). A sterile needle (BD Microlance 3; $27 \mathrm{G} \mathrm{1/2";}$ $0.3 \mathrm{~mm} \times 13 \mathrm{~mm}$ ) was inserted in the left side of the telencephalon, guided by landmarks on the head, following a dorso-ventral axis. After positioning the needle tip on the surface of the skull, the pressure was applied vertically to achieve a penetration depth of $1.5 \mathrm{~mm}$ in the dorsal area of left side of telencephalon. Zebrafish were kept in fresh water and regularly observed to make sure they fully recovered and behave normally (feeding and swimming). To analyze the effects of injury, fish were euthanized with an overdose of MS 222 at different time points after lesion $(1,4,7$ and 15 days post-lesion (dpl). Brains were dissected carefully and processed for mRNA extraction or in situ hybridization and immunohistochemistry.

\section{$R N A$ extraction and quantitative real-time $P C R$}

BDNF mRNA quantification was performed at different times after the lesion: $1 \mathrm{dpl}$ (1 day post lesion), $4 \mathrm{dpl}, 7 \mathrm{dpl}$ and $15 \mathrm{dpl}$. For each time point, 10 injured telencephali were pooled (both right and left telencephalic hemispheres were removed) before RNA extraction proceeding. For the control condition, we pooled 10 non-injured telencephali and performed RNA extraction. The protocol was repeated in two additional experiments (100 animals in total). Telencephali were sonicated (10 s, three times) in $250 \mu \mathrm{l}$ Trizol Reagent (Gibco, Carlsbad, CA, USA), and total RNA was extracted according to the manufacturer's protocol. Reverse transcription was carried out by incubating $0,5 \mu \mathrm{g}$ total RNA with $1 \mu \mathrm{l}$ of random primer oligonucleotides, $2.5 \mathrm{mMdNTPs}$ and $50 \mathrm{U}$ 
MMLV-RT (Promega) in the appropriate buffer for $10 \mathrm{~min}$ at $65^{\circ} \mathrm{C}$, and $90 \mathrm{~min}$ at $37^{\circ} \mathrm{C}$. Polymerase chain reaction (PCR) experiments were performed in the thermocycler coupled to the MyiQ detector (Bio-Rad. Hercules, CA, USA) using Q SYBR-Green Supermix (Bio-Rad) according to the manufacturer's protocol. The following primers were used: BDNF (fw) 5'ATAGTAACGAACAGGATGG-3'; BDNF (rev) 5'-GCTCAGTCATGGGAGTCC-3'; PCNA (fw) 5'-CTCACAGACCAGCAACGTCG-3'; PCNA (rev) 5'-GGACAGAGGAGTGGCTTTGG-3'; GAPDH (fw) 5'-CGCTGGCATCTCCCTCAA-3; GAPDH (rev) 5'TCAGCAACACGATGGCTGTAG-3'. GAPDH was used to normalize the expression levels of genes of interest. Melting curve and PCR efficiency analyses were performed to confirm correct amplification. Comparisons between groups were performed using a statistical Student's t-test. The results were analyzed using multiple testing Benjamini-Hochberg correction. Error bars correspond to the standard error of the mean $(\mathrm{SEM}) . \mathrm{P}<0.05$ was considered statistically significant $(* \mathrm{p}<0.05 ; * * \mathrm{p}<0.005 ; * * * \mathrm{p}<0.001 ; * * * * \mathrm{p}<0.0001)$.

\section{Riboprobe synthesis}

For BDNF riboprobe synthesis, we used a pCMV-Sport 6.1 plasmid containing the fulllength BDNF cDNA (Unigene DR.132862; Entrez Gene 58118). Antisense and sense riboprobes were generated with DIG RNA Labelling Mix (Roche Diagnostic, Indianapolis, IN) by in vitro transcription, using T7 polymerase (Roche-diagnostic) and SP6 polymerase (Roche-diagnostic) on plasmid linearized by EcoRI and Not1.

\section{In situ hybridization (ISH)}

Brains were quickly removed at the different time points $(1,4,7,15 \mathrm{dpl})$, and fixed overnight $(\mathrm{ON})$ at $4 \mathrm{C}^{\circ}$ in PBS-PAF $4 \%$. They were processed for paraffin embedding. Microtome sections $(7 \mu \mathrm{m})$ were mounted on poly-lysine slides. Deparaffinized sections were gradually hydrated, washed in PBS-NaCl (0.85\%) and post-fixed for 20 minutes (min) in PBS-PFA 4\%. Protocol for double staining ISH/immunohistochemistry was previously published by Coumailleau et al., 2014. The brain sections were rinsed in PBS and treated for $7 \mathrm{~min}$ with proteinase $\mathrm{K}$ $(2 \mathrm{mg} / \mathrm{ml})$ diluted in PBS at $37^{\circ} \mathrm{C}$. Slides were then rinsed as follows: $20 \mathrm{~min}$ in 4\% PBS-PAF, 10 $\mathrm{min}$ in PBS and $10 \mathrm{~min}$ in standard saline citrate (SSC 2x). The sections were incubated $\mathrm{ON}$ at $62.5^{\circ} \mathrm{C}$ in a moist chamber with the probes $(1.5 \mu \mathrm{g} / \mathrm{ml})$ diluted in hybridization buffer (formamide $50 \%$, SSC 2X, Denhart $5 \mathrm{X}$, yeast tRNA $50 \mu \mathrm{g} / \mathrm{ml}$, EDTA $4 \mathrm{mM}$, dextran sulfate $2.5 \%$ ). The following day, slides were rinsed with SCC 2x, SCC 2x/formamide 50\%, SSC 0.2x and SSC 0.1x. Next, they were dipped in Tris- $\mathrm{HCl} / \mathrm{NaCl}$ buffer $(100 \mathrm{mM}$, Tris- $\mathrm{HCl} \mathrm{pH} 7.5,150 \mathrm{mMNaCl})$ and 
washed in the same buffer containing $0.1 \%$ Triton and $0.5 \%$ of milk powder. Sections were incubated $\mathrm{ON}$ at room temperature (RT) with anti-digoxigenin alkaline phosphatase Fab fragments (1:2000, Roche Diagnostic). On the next day, slides were rinsed in Tris- $\mathrm{HCl} / \mathrm{NaCl}$ buffer and washed three times with Tris-HCl $100 \mathrm{mM}(\mathrm{pH} 8)$ containing $\mathrm{NaCl}(100 \mathrm{mM})$ and $\mathrm{MgCl} 2(10 \mathrm{mM})$. The hybridization signal was revealed with the HNPP/Fast-Red detection kit (Roche Diagnostic) after 6 hours according to the manufacturer's instructions. Sections were washed several times in PBS, mounted in Vectashield medium containing DAPI and cover-slipped for microscopic analysis.

The specificity of the ISH reaction was checked on adjacent sections with the sense riboprobe.

\section{Immunohistochemistry (IHC)}

Brain sections processed for ISH, underwent the immuhistochemical study. The ISH reaction was stopped $5 \mathrm{~min}$ in PBS-PAF 4\%, and the IHC was performed as follows: hybridized sections were washed in PBS and in PBS/Triton (0.05\%), and incubated ON at RT with the primary antibodies presented in Table 1. All antibodies were diluted in PBS containing $0.5 \%$ milk powder. Sections were washed three times in PBS-Triton $0.05 \%$ and incubated with goat anti-mouse Alexa Fluor 488 for 2 hours. Tissue sections were washed in PBS-Triton 0,05\%, and slides were mounted with the Vectashield medium containing DAPI for nuclei counter-staining (Vector Laboratories, Burlingame, CA).

The primary antibodies used for IHC have been previously characterized for their specificity in zebrafish. In line with previous studies, PCNA monoclonal antibody (RRID AB_477413) has been shown to label cell nuclei in different species including zebrafish (Wullimann and Puelles 1999; Pellegrini et al. 2007, März et al 2011). The staining generated by this antibody is observed in neurogenic zones lining the ventricle similar to BrdU labeling (Zupanc et al. 2005). The antiacetylated tubulin monoclonal antibody (RRID AB_477585) we used to identify neurons has been previously documented for its specificity in zebrafish. The staining observed is cytoplasmic similar to that observed in previous study and is never detected in radial glial cells (Pellegrini et al. 2007; Huang and Sato, 1998; Chitnis and Kuwada, 1990). HuC/D antibody (RRID AB_221448) has been shown to be suitable for $\mathrm{Hu}$ detection in many species including zebrafish. The staining observed with this antibody is nuclear, consistent with other studies. Moreover, we never observed staining in radial glial cells lining the ventricles (Forlano et al. 2001; Pellegrini et al. 2007, Kroehne et al., 2011) 


\section{Microscopy}

Sections were observed with an epifluorescence microscope (Olympus Provis, equipped with a DP71 digital camera), or a confocal microscope Leica SP2. Images were processed with either the Olympus (Cell) Zeiss (AxioVision4) or Leica (LCS Lite) software. Micrographs were acquired in TIFF format and adjusted for light and contrast before being assembled on plates using

\section{Photoshop CS4.}

\section{Statistical analysis}

The number of BDNF mRNA expressing cells was evaluated on photographs of transversal serial sections of 4 telencephali for each time points $(1,4,7$ and $15 \mathrm{dpl})$. The cells quantification in the injured side was made on 5 sections, corresponding to the thickness of the injury. Quantification of BDNF mRNAexpressing cells was also performed on non-injured side of telencephalon (control side). Cell counting was made on photographs (magnification 10x) using the following programs: a) Cell-Sens Standard software (8.1 version) to delimit the area of the telencephalon; b) Cell Counter (Manual) of Image J software to count the positive cells; c) Graphpad Software to produce graphs. The significance was calculated using t-student test. Groups were analyzed using multiple testing. The mean value was corrected by Benjamini-Hochberg. Error bars correspond to the standard error of the mean $(\mathrm{SEM}) . \mathrm{P}<0.05$ was considered statistically significant $(* \mathrm{p}<0.05$; $* * \mathrm{p}<0.005 ; * * \mathrm{p}<0.001 ; * * * \mathrm{p}<0.0001)$

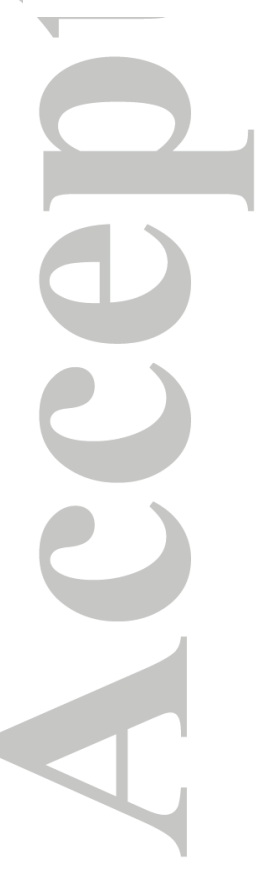




\section{RESULTS}

Bdnf expression in homogenates of telencencephali at 4 time intervals from the injury

In order to evaluate BDNF mRNA level modifications, quantitative PCR experiments were conducted at 1, 4, 7, 15 days post lesion (dpl) in 10 injured zebrafish telencephali and compared to 10 non-injured telencephali, used as controls. Each experiment was repeated four times.

At $1 \mathrm{dpl}$ the amount of BDNF mRNA was significantly increased, compared to unlesioned telencephalon (Fig. 1A). At 4, 7 and $15 \mathrm{dpl}$ the levels lowered progressively, although they were significantly increased when compared to controls (Fig. 1A).

To assess the proliferative response, we also measured the proliferating cell nuclear antigen (PCNA) mRNA expression, in injured and non-injured telencephali. At 1, 4 and 7 dpl, PCNA mRNA levels were significantly increased compared to unlesioned controls, showing a peak at 4 dpl (Fig. 1B).

\section{$B D N F m R N A$ cells distribution in telencephali at 4 time intervals from the injury}

In order to evaluate the precise distribution and variation in the number of BDNF mRNA expressing cells after injury, ISH was performed on serial sections of telencephali at 1, 4, 7 and 15 dpl. Experiment specificity was provided by sense riboprobe showing absence of staining (data not shown).

BDNF mRNA expression was seen in small round cells mostly scattered in the dorsal telencephalon, largely surrounding the injury in antero-posterior orientation. At $1 \mathrm{dpl}$ the signal strongly increased in the dorsal and central zone of the dorsal telencephalon (Fig. 2a-c1) compared to contralateral side (Fig. 2a2-c2). At 4, 7 and 15 dpl, BDNF expression moderately increased, especially in the dorsal and lateral zone of the dorsal telencephalon (Fig. 3a-c1, Fig. 4a-c1; Fig. 4ac1).

We also evaluated the number of BDNF mRNA expressing cells on photographs of transversal serial sections of injured and non-injured telencephali using the program Cell Counter (Manual) of Image J software. The significance was calculated using t-student test, and graphs produced using by Graphpad Software.

At $1 \mathrm{dpl}$, the number of BDNF cells in the injured telencephalon displayed remarkable increase compared to the control; at 4 and $7 \mathrm{dpl}$ the positive cells revealed a moderate increase, and at $15 \mathrm{dpl}$ only a slight increase (Fig. 6).

Successively, BDNF mRNA expressing cells was evaluated in the lesioned side of telencephali and in the contralateral unlesioned side. At each time points, the number of BDNF 
mRNA expressing cells was significantly higher compared to the contralateral side (Fig. 7). The highest difference was observed at $1 \mathrm{dpl}$, whereas the lowest at $15 \mathrm{dpl}$, as shown in the graphs (Fig. 7).

Furthermore, we compared the values of BDNF mRNA expressing cells detected at 4, 7, 15 dpl to $1 \mathrm{dpl}$, the time interval corresponding to the highest increased level of BDNF. In the injured side, the number of positive cells significantly decreased over the time points (Fig. 8A). We also quantified the number of BDNF mRNA expressing cells in the contralateral side. Although the overall number of positive cells was less than the injury side, we observed a significant increase over the time points (Fig. 8B).

$B D N F m R N A$ expressing-cells in the injured telencephalon are neurons

In a previous study (Cacialli et al., 2016), we identified BDNF expressing cells as neurons in the brain of adult zebrafish. In order to verify whether also in case of injury neurons express BDNF, we performed double staining ISH/IHC, employing antibodies directed against markers of neurons, either early differentiated (HuC/D) and mature (acetylated-tubulin).

As shown in Fig. 9, the large majority of BDNF mRNA expressing cells in the lesioned side were seen in the vicinity of $\mathrm{HuC} / \mathrm{D}$ positive cells (Fig. 9a-c). Only seldom co-staining of BDNF/HuC/D was observed in some cells (Fig. 9d-f). A similar pattern was also observed in the control side (data not shown).

In contrast, BDNF mRNA expressing cells showed immunoreactivity to acetylated-tubulin in the lesioned (Fig. 10a-d) and contralateral side (data not shown).

Based on the increased levels of PCNA mRNA after lesion previously observed (Fig. 1B), we then investigated co-localization of BDNF mRNA expressing cells and PCNA in neurons. We never detected BDNF transcripts in cell positive to PCNA (Fig. 11b-f). As clearly shown in Fig 11a, PCNA-immunoreactive cells were observed in the ventricular regions. 


\section{DISCUSSION}

Our findings represent the first report concerning BDNF involvement in injured brain of nonmammalian vertebrates. Our results demonstrated that: a) the peak of BDNF mRNA expression was observed early after the lesion in the area and in neurons surrounding the lesion; b) BDNF mRNA induction was observed in mature neuronal populations.

\section{$B D N F m R N A$ levels increased in the brain after injury}

Our results displayed a remarkable increase of BDNF mRNA levels in homogenates of the whole lesioned telencephalon at $1 \mathrm{dpl}$, compared to control unlesioned animals, and gradual decrease over 4, 7 and $15 \mathrm{dpl}$. Similar to the injury performed in zebrafish, severe penetrating TBI caused an increase of BDNF mRNA levels in rat brain homogenates (Oyesiku et al. 1999). Comparably, BDNF protein levels, measured by reverse phase protein microarray, increased in rat injured brains, and no significant level variations were reported over 2 weeks following the injury (Rostami et al 2014). In contrast, mild severity level of TBI obtained by lateral percussion displayed unchanged BDNF mRNA levels in hippocampal homogenates of 17 days old rat pups (Schober et al 2012)

BDNF mRNA expressing cells are neurons and their number increased mostly at early time after injury

In the present study, quantitative data referring to BDNF mRNA expressing cells in the whole dorsal telencephalon clearly increased in number early, at $1 \mathrm{dpl}$, compared to control animals. The number of BDNF mRNA expressing cells decreased over the time after lesion, but remained significantly higher than in controls. These findings match with RT-PCR data, collected on the whole telencephalic extracts.

In situ hybridization/immunohistochemistry analysis demonstrated that BDNF mRNA was colocalized with acetylated-tubulin, very rarely with $\mathrm{HuC} / \mathrm{D}$ and never with PCNA. Thus we can retain by far the majority of BDNF mRNA expressing cells as mature neuronal populations, in the lesioned telencephalon, throughtout the entire examined post injury period. These findings are consistent with our previous observations in the brain of juvenile zebrafish and adult unlesioned brain of zebrafish (Cacialli et al, 2016) and the general statement that consider BDNF a product of neuronal synthesis (Castren et al 1995; Schmidt-Kastner et al 1996; Dalton et al 2009; Quartu et al 2010; D'Angelo et al 2014). Furthermore, our results show that BDNF expressing cells constitute a different cell population than PCNA. We indeed observed different timing in the maximum increase of BDNF mRNAs, which occurred soon after the lesion, and the peak of PCNA mRNA levels, 
detected at $4 \mathrm{dpl}$. This time frame is too short for neuronal precursor cells migration, moving from ventricular zone to the injury site where they differentiate into mature neurons (Kroehne et al 2011, Kishimoto et al 2012, Diotel et al., 2013).

\section{BDNF mRNA expressing neurons were more numerous in the lesioned side}

BDNF mRNA expressing neurons were more numerous in the injured side compared to the contralateral at each time points $(1,4,7$, and $15 \mathrm{dpl})$. This difference was much remarkable $1 \mathrm{dpl}$, and became less evident from $4 \mathrm{dpl}$ onwards, while a slight increase of BDNF mRNA expressing neurons was seen from 4 to $15 \mathrm{dpl}$ in the contralateral side.

In rodents the increase of BDNF mRNA expressing cells was usually reported in the contralateral side of: a) cortex and hippocampus 2 hours after mild TBI (by compression) (Skoglosa et al. 1999); b) occipital cortex and hippocampus 24 hours and 7 days after mild TBI (by lateral fluid pression) (Griesbach et al 2002); c) hippocampus 3 days after mild TBI (by percussion) (Schober 2012); d) hippocampus 2 weeks following severe penetrating TBI (Rostami et al 2014).

However, within 24 hours of the lesion, contrasting results were reported in rodents: a) injury side increase of BDNF mRNA expressing cells in the hippocampus after $3-6$ hours following a mild severity level of TBI (by lateral fluid percussion) (Hicks et al1999), and in the thalamus 8 hours after severe penetrating TBI (Felderhoff-Mueser et al. 2002); b) injury side decrease of BDNF mRNA expression in the hippocampus at 1 day after severe penetrating TBI (Rostami et al 2014); c) bilateral increase in the hippocampus and dentate gyrus after 1 hour up to 72 hours following mild TBI, obtained by lateral gas (Yang et al 1996) and fluid (Hicks et al 1997) percussion.

\section{Could BDNF receptors exert different responses in zebrafish and rodent brain?}

It is known that $b d n f$ undergoes post-translational mechanisms leading to proBDNF and mature BDNF, which exert opposite effects (Deinhardt and Chao, 2013). The receptor TrkB binds with high affinity to mature BDNF, mediating survival of neurons, while the receptor p75, with sortilin, binds with high affinity to proBDNF, mediating apoptotic events (for a review see Meeker and Williams, 2015). Thus, the post-injury loss of neurons after brain injury in rodent could be ascribed to the induction of p75 receptor and to some extent to proBDNF (Rostami et al 2014; Alder et al 2016). As further evidence, $p 75$ mutant mice as well as mice treated with the p75 antagonist or the TrkB agonist exhibited reduced post traumatic events, such as neuronal death and degeneration, and 
reduced astrocytosis (Alder et al 2015). On the opposite, adult gerbil CA1 neurons, which showed BDNF and TrkB colocalization, resulted resistant to damage during forebrain ischemia (Ferrer et al 1997).

In zebrafish instead, the fast and complete recovery of the telencephalic lesioned area and the increase of BDNF mRNA expressing neurons following injury could be related to the possible presence of mature BDNF exerting trophic effect through TrkB receptor. Indeed, the latter was previously described in zebrafish (Abbate et al 2014; Montalbano et al 2016; Gatta et al 2016). However, further studies are necessary in this direction, to clarify the role of BDNF proteins and the related receptors.

\section{Concluding remarks}

Comparing our data with numerous studies in the literature, we can define BDNF increasing after TBI as an early response to damage in both zebrafish and rodents. However, remarkable difference exists: in zebrafish, BDNF mRNA presence persists around the lesioned area, while in rodents BDNF expression, because of neuronal loss and glial scar formation in the injured area, persists only in the contralateral side. Considering the complete repair of the damaged area in fish, it could be tempting to consider BDNF as a factor contributing to create a permissive environment that enables the establishment of new neuronal population in damaged brain. However, further studies are still necessary to shed light on BDNF involvement in teleost brain repair.

\section{ACKNOWLEDGMENTS}

We greatly appreciated the help of the staff of the zebrafish Biosit facility (Laboratoire de Physiologie et Génétique des Poissons, INRA, Rennes. We thank Mr Antonio Calamo for his skillful assistance during elaboration of all graphics and images. We are thankful for INSERM and University of Rennes 1 (France) for funding our research. The European Trans Channel Neuroscience Network Program (TC2N) supported this research.

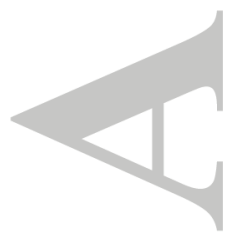

\section{AUTHOR CONTRIBUTIONS}


Conceived and designed the experiments: EP, CL, OK, LDA. Performed the experiments: P. Cacialli, EP, MMG, P. Coumailleau. Analyzed the data: P. Cacialli, OK, EP, CL. Wrote the paper: CL, P. Cacialli, EP, LDA, P. Coumailleau,.
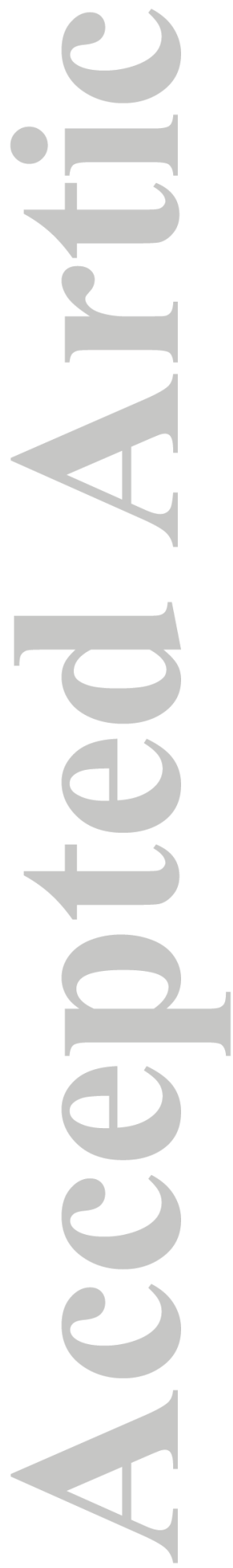


\section{FIGURE LEGENDS}

Fig. 1 BDNF (A) and PCNA (B) mRNAs levels in unlesioned (UL) and lesioned telencephali at different time points after the lesion $(1,4,7,15 \mathrm{dpl})$. The asterisks indicate statistically significant differences. Groups were analyzed using t-test. $\mathrm{P}<0.05$ was considered statistically significant $(* \mathrm{p}<0.05 ; * * \mathrm{p}<0.005 ; * * * \mathrm{p}<0.001 ; * * * * \mathrm{p}<0.0001)$. The graphs present the mean value $+/-$ of the standard deviation.

Fig. 2 BDNF mRNA expression at $1 \mathrm{dpl}$ on transversal rostro-caudal sections of injured (left side) and non-injured telencephali (right side). a-c low magnification of both telencephalic sides. a1-c1 high magnification of injured side. a2-c2 high magnification of non-injured side. In a1c1 cell nuclei are labeled with Dapi (blue). Dm: medial zone of the dorsal telencephalon; Dc: central zone of the dorsal telencephalon; TelV: ventral telencephalon. Epifluorescence microscope, scale bar $200 \mu \mathrm{m}$ in a, b, c; $60 \mu \mathrm{m}$ in a1- c1 and a2 - c2.

Fig. 3 BDNF mRNA expression at $4 \mathrm{dpl}$ on transversal rostro-caudal sections of injured (left side) and non-injured telencephali (right side). a-c low magnification of both telencephalic sides. a1-c1 high magnification of injured side. a2-c2 high magnification of non-injured side. In a1c1 cell nuclei are labeled with Dapi (blue). Dm: medial zone of the dorsal telencephalon; Dc: central zone of the dorsal telencephalon; D1: lateral zone of the dorsal telencephalon; Dp: posterior zone of the dorsal telencephalon; TelV: ventral telencephalon; v: ventricle. Epifluorescence microscope, scale bar $=250 \mu \mathrm{m}$ in a-c; $60 \mu \mathrm{m}$ in a1- c1 and a2 - c2.

Fig. 4 BDNF mRNA expression at $7 \mathrm{dpl}$ on transversal rostro-caudal sections of injured (left side) and non-injured telencephali (right side). a-c low magnification of both telencephalic sides. a1-c1 high magnification of injured side. a2-c2 high magnification of non-injured side. In a1c1 cell nuclei are labeled with Dapi (blue). Dm: medial zone of the dorsal telencephalon; Dc: central zone of the dorsal telencephalon; TelV: ventral telencephalon; v: ventricle. Epifluorescence microscope, scale bar $200 \mu \mathrm{m}$ in a, b, c; $60 \mu \mathrm{m}$ in a1- c1 and a2 - c2.

Fig. 5 BDNF mRNA expression at $15 \mathrm{dpl}$ on transversal rostro-caudal sections of injured (left side) and non-injured telencephali (right side). a-c low magnification of both telencephalic sides. a1-c1 high magnification of injured side. a2-c2 high magnification of non-injured side. In a1c1 cell nuclei are labeled with Dapi (blue). Dm: medial zone of the dorsal telencephalon; Dc: 
central zone of the dorsal telencephalon; TelV: ventral telencephalon; v: ventricle. Epifluorescence microscope, scale bar $200 \mu \mathrm{m}$ in a, b, c; $60 \mu \mathrm{m}$ in a1- c1 and a2 - c2.

Fig. 6 Mean number of BDNF mRNAs expressing cells in 5 sections of 4 telencephali of controls and 4 lesioned telencephali at 1,4,7 and $15 \mathrm{dpl}$, (in total 20 brains). Asterisks indicate statistically significant difference between injured and control animals $(* p<0.05$; $* * \mathrm{p}<0.005 ; * * * \mathrm{p}<0.001 ; * * * * \mathrm{p}<0.0001$ using Student's t test). The graphs present the mean value $+/-$ of the standard deviation.

Fig. 7 Mean number of BDNF mRNAs expressing cells in 5 sections of 4 injured and contralateral side of telencephalon at 1, 4, 7 and $15 \mathrm{dpl}$ (in total 16 brains). Asterisks indicate statistically significant difference between the values obtained in injured and contralateral side at each interval time $\left(* \mathrm{p}<0.05 ;{ }^{*} \mathrm{p}<0.01 ; * * * \mathrm{p}<0.005\right.$ using Student's $\mathrm{t}$ test). The graphs present the mean value $+/-$ of the standard deviation.

Fig. 8 Number of BDNF mRNA expressing cells in injured (A) and contralateral (B) side of telencephalon at 1, 4, 7 and $15 \mathrm{dpl}$. Asterisks indicate significant difference of the values at 4, 7, $15 \mathrm{dpl}$ compared to the value obtained at $1 \mathrm{dpl}\left({ }^{*} \mathrm{p}<0.05 ; *^{*} \mathrm{p}<0.005\right.$ using Student's $\mathrm{t}$ test). The graphs present the mean value $+/-$ of the standard deviation

Fig. 9 Double ISH/IHC staining in injured (left side) telencephalon of 1 dpl zebrafish showing BDNF mRNA (red) and HuC/D protein (green). $\mathrm{c}$ is high magnification of the rectangular areas showed respectively in and B. D, E. F high magnification of medial zone of telencephalon showing $\mathrm{BDNF} / \mathrm{HuC} / \mathrm{D}$ cell (arrow). In $\mathrm{c}$ and $\mathrm{f}$ red-green fluorescence was converted in magenta-green colors to make the figures more accessible to male readers who are red-green color blind. Dl: lateral zone of the dorsal telencephalon; TelV: ventral telencephalon; v: ventricle. Epifluorescence microscope, scale bar a-b $200 \mu \mathrm{m}$; c $50 \mu \mathrm{m}$; d-f $30 \mu \mathrm{m}$.

Fig. 10 Double ISH/IHC staining in injured (left side) telencephalon of 1 dpl zebrafish showing BDNF mRNA (red) and acetylated-tubulin (green). B, c, d are magnifications of the rectangular area showed in a. In d cell nuclei are labeled in blue with DAPI. In c and d redgreen fluorescence was converted in magenta-green colors to make the figures more accessible to male readers who are red-green color blind. Dl: lateral zone of the dorsal 
telencephalon; Dp: posterior zone of the dorsal telencephalon. Epifluorescence microscope, scale bar: a $200 \mu \mathrm{m}$; b-c-d $25 \mu \mathrm{m}$

Fig. 11 Double ISH/IHC staining in injured (left side) telencephalon at $1 \mathrm{dpl}$ showing BDNF mRNA (magenta) and PCNA protein (green). (a) is a representative section of the injured telencephalon showing cells containing BDNF mRNA (magenta dots) and PCNA (green dots). At low (b), middle (c, d, f) and high (f) magnification, BDNF mRNA expressing cells were scattered in the parenchyma and PCNA positive cells were lining the telencephalic ventricle. $\mathrm{c}$ and e are magnifications of the rectangular areas showed in B. Dc: central zone of the dorsal telencephalon; Dl: lateral zone of the dorsal telencephalon; Dm: medial zone of the dorsal telencephalon; Dp: posterior zone of the dorsal telencephalon; v: ventricle; Vd: dorsal zone of the ventral telencephalon; $\mathrm{Vv}$ : ventral zone of the ventral telencephalon. Epifluorescence microscope (b-e), confocal microscope (Ffscale bar: B $200 \mu \mathrm{m}$; c-d-e $60 \mu \mathrm{m}$; f $40 \mu \mathrm{m}$

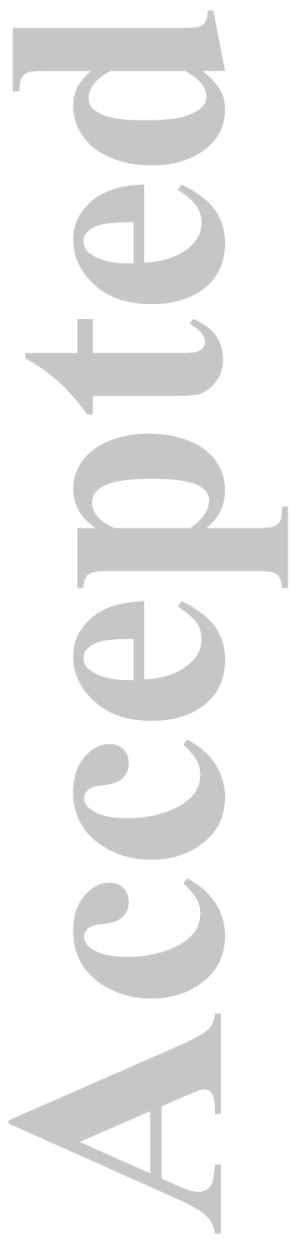




\section{REFERENCES}

Abbate F, Guerrera MC, Montalbano G, Levanti MS, Germana GP, Navarra M, Laura R, Vega JA, Ciriaco E, Germana A. 2014. Expression and anatomical distribution of TrkB in the encephalon of the adult zebrafish (Daniorerio). Neuroscience Letters 563:66-69.

Adolf B, Chapouton P, Lam CS, Topp S, Tannhauser B, Strahle U, Gotz M, Bally-Cuif L. 2006. Conserved and acquired features of adult neurogenesis in the zebrafish telencephalon. Developmental Biology 295(1):278-293.

Alder J, Fujioka W, Giarratana A, Wissocki J, Thakkar K, Vuong P, Patel B, Chakraborty T, Elsabeh R, Parikh A, Girn HS, Crockett D, Thakker-Varia S. 2016. Genetic and pharmacological intervention of the p75NTR pathway alters morphological and behavioural recovery following traumatic brain injury in mice. Brain Injury 30(1):48-65.

Alunni A, Bally-Cuif L. 2016. A comparative view of regenerative neurogenesis in vertebrates. Development 143(5):741-753.

Bath KG, Lee FS. 2006. Variant BDNF (VAl66Met) impact on brain structure and function. Cognitive Affective \& Behavioral Neuroscience 6(1):79-85.

Baumgart EV, Barbosa JS, Bally-Cuif L, Gotz M, Ninkovic J. 2012. Stab wound injury of the zebrafish telencephalon: A model for comparative analysis of reactive gliosis. Glia 60(3):343357.

Becker CG, Becker T. 2008.Adult zebrafish as a model for successful central nervous system regeneration.RestorativeNeurology and Neuroscience 26(2-3):71-80.

Broglio C, Gomez A, Duran E, Ocana FM, Jimenez-Moya F, Rodriguez F, Salas C. 2005. Hallmarks of a common forebrain vertebrate plan: Specialized pallial areas for spatial, temporal and emotional memory in actinopterygian fish. Brain ResearchBulletin 66(4-6):277281.

Cacialli P, Gueguen MM, Coumailleau P, D'Angelo L, Kah O, Lucini C, Pellegrini E. 2016. BDNF Expression in Larval and Adult Zebrafish Brain: Distribution and Cell Identification. Plos One 11(6).

Castren E, Thoenen H, Lindholm D. 1995. Brain-derived neurotrophic factor messenger-RNA is expressed in the septum, hypothalamus and in adrenergic brain-stem nuclei of adult-rat brain ans is increased by osmotic stimulation in the paraventricular nucleus.Neuroscience 64(1):7180.

Coumailleau P, Kah O., 2014. Cyp19a1 (aromatase) expression in the Xenopus brain at different developmental stages. J Neuroendocrinol, 26(4): 226-236). 
D'Angelo L, De Girolamo P, Lucini C, Terzibasi ET, Baumgart M, Castaldo L, Cellerino A. 2014. Brain-Derived Neurotrophic Factor: mRNA Expression and Protein Distribution in the Brain of the Teleost Nothobranchiusfurzeri. 522(5):1004-1050. D-Angelo L, Lossi L, Merighi A,

de Girolamo P. 201:. Anatomical features for the adequate choice

of experimental animal models in biomedicine: I. Fishes. Annals of AnatomyAnatomischerAnzeiger 205:75-84.

Dalton VS, Roberts BL, Borich SM. 2009. Brain derived neurotrophic factor and trk B mRNA expression in the brain of a brain stem-spinal cord regenerating model, the European eel, after spinal cord injury. NeuroscienceLetters 461(3):275-279.

De Felice E, Porreca I, Alleva E, Girolamo P, Ambrosino C, Ciriaco E, Germana A, Sordino P. 2014. Localization of BDNF expression in the developing brain of zebrafish. Journal of Anatomy 224(5):564-574.

Deinhardt K, Chao MV. 2014. Shaping neurons: Long and short range effects of mature and proBDNFsignalling upon neuronal structure. Neuropharmacology 76:603-609.

Diotel N, Vaillant C, Gabbero C, Mironov S, Fostier A, Gueguen MM, Anglade I, Kah O, Pellegrini E. 2013. Effects of estradiol in adult neurogenesis and brain repair in zebrafish. Hormones and Behavior 63(2):193-207.

Felderhoff-Mueser U, Sifringer M, Pesditschek S, Kuckuck H, Moysich A, Bittigau P, Ikonomidou C. 2002. Pathways leading to apoptotic neurodegeneration following trauma to the developing rat brain.Neurobiology of Disease 11(2):231-245.

Ferrer I, Ballabriga J, Marti E, Pozas E, Planas AM, Blasi J. 1997. BDNF and TrkB co-localize in CA1 neurons resistant to transient forebrain ischemia in the adult gerbil. Journal of Neuropathology and Experimental Neurology 56(7):790-797.

Gatta C, Altamura G, Avallone L, Castaldo L, Corteggio A, D'Angelo L, de Girolamo P, Lucini C. 2016. Neurotrophins and Their Trk-Receptors in the Cerebellum of Zebrafish. Journal of Morphology 277(6):725-736.

Gemberling M, Bailey TJ, Hyde DR, Poss KD. 2013. The zebrafish as a model for complex tissue regeneration. Trends in Genetics 29(11):611-620.

Grandel H, Kaslin J, Ganz J, Wenzel I, Brand M. 2006. Neural stem cells and neurogenesis in the adult zebrafish brain: Origin, proliferation dynamics, migration and cell fate. Developmental Biology 295(1):263-277.

Griesbach GS, Hovda DA, Molteni R, Gomez-Pinilla F. 2002. Alterations in BDNF and synapsin I within the occipital cortex and hippocampus after mild traumatic brain injury in the 
developing rat: Reflections of injury-induced neuroplasticity. Journal of Neurotrauma 19(7):803-814.

Griesbach GS, Hovda DA, Molteni R, Wu A, Gomez-Pinilla F. 2004. Voluntary exercise following traumatic brain injury: Brain-derived neurotrophic factor upregulation and recovery of function. Neuroscience 125(1):129-139.

Griesbach GS, Hovda DA, Gomez-Pinilla F. 2009. Exercise-induced improvement in cognitive performance after traumatic brain injury in rats is dependent on BDNF activation. Brain Research 1288:105-115.

Hicks RR, Numan S, Dhillon HS, Prasad MR, Seroogy KB. 1997. Alterations in BDNF and NT-3 mRNAs in rat hippocampus after experimental brain trauma. Molecular Brain Research 48(2):401-406.

Hicks RR, Li CY, Zhang LX, Dhillon HS, Prasad MR, Seroogy KB. 1999. Alterations in BDNF and trkB mRNA levels in the cerebral cortex following experimental brain trauma in rats. Journal of Neurotrauma 16(6):501-510.

KhorshidAhmad T, Acosta C, Cortes C, Lakowski TM, Gangadaran S, Namaka M. 2016. Transcriptional Regulation of Brain-Derived Neurotrophic Factor (BDNF) by Methyl CpG Binding Protein 2 (MeCP2): a Novel Mechanism for Re-Myelination and/or Myelin Repair Involved in the Treatment of Multiple Sclerosis (MS). Molecular Neurobiology 53(2):10921107.

Kishimoto N, Shimizu K, Sawamoto K. 2012.Neuronal regeneration in a zebrafish model of adult brain injury. Disease Models \& Mechanisms 5(2):200-209.

Kroehne V, Freudenreich D, Hans S, Kaslin J, Brand M. 2011. Regeneration of the adult zebrafish brain from neurogenic radial glia-type progenitors. Development 138(22):4831-4841.

Kyritsis N, Kizil C, Brand M. 2014. Neuroinflammation and central nervous system regeneration in vertebrates. Trends in Cell Biology 24(2):128-135.

Lum T, Huynh G, Heinrich G. 2001. Brain-derived neurotrophic factor and TrkB tyrosine kinase receptor gene expression in zebrafish embryo and larva. International Journal of Developmental Neuroscience 19(6):569-587.

Marz M, Schmidt R, Rastegar S, Strahle U. 2011. Regenerative Response Following Stab Injury in the Adult Zebrafish Telencephalon. Developmental Dynamics 240(9):2221-2231.

Meeker RB, Williams KS. 2015. The p75 neurotrophin receptor: at the crossroad of neural repair and death. Neural Regeneration Research 10(5):721-725.

Migaud M, Butruille L, Duittoz A, Pillon D, Batailler M. 2016.Adult neurogenesis and reproductive functions in mammals. Theriogenology 86(1):313-323. 
Molendijk ML, Spinhoven P, Polak M, Bus BAA, Penninx B, Elzinga BM. 2014. Serum BDNF concentrations as peripheral manifestations of depression: evidence from a systematic review and meta-analyses on 179 associations (N=9484). MolecularPsychiatry 19(7):791-800.

Montalbano G, Mania M, Guerrera MC, Abbate F, Laura R, Navarra M, Vega JA, Ciriaco E, Germana A. 2016. Morphological differences in adipose tissue and changes in BDNF/Trkb expression in brain and gut of a diet induced obese zebrafish model. Annals of AnatomyAnatomischerAnzeiger 204:36-44.

Oyesiku NM, Evans CO, Houston S, Darrell RS, Smith JS, Fulop ZL, Dixon CE, Stein DG. 1999. Regional changes in the expression of neurotrophic factors and their receptors following acute traumatic brain injury in the adult rat brain. Brain Research 833(2):161-172.

Pellegrini E, Mouriec K, Anglade I, Menuet A, Le Page Y, Gueguen MM, Marmignon MH, Brion F, Pakdel F, Kah O. 2007. Identification of aromatase-positive radial glial cells as progenitor cells in the ventricular layer of the forebrain in zebrafish. Journal of Comparative Neurology 501(1):150-167.

Pellegrini E., Coumailleau P, Kah O, Diotel N.Aromatase and estrogens: Involvement in constitutive and regenerative neurogenesis in adult zebrafish. In K.Duncan (Ed.), Estrogen effects on brain injury. Academical Press, Elsevier, 2014, pp51-71.

Quartu M, Serra MP, Boi M, Melis T, Ambu R, Del Fiacco M. 2010. Brain-derived neurotrophic factor (BDNF) and polysialylated-neural cell adhesion molecule (PSA-NCAM): codistribution in the human brainstem precerebellar nuclei from prenatal to adult age. Brain Research 1363:49-62.

Reichardt LF. 2006. Neuratrophin-regulated signalling pathways. Philosophical Transactions of the Royal Society B-Biological Sciences 361(1473):1545-1564.

Rostami E, Krueger F, Plantman S, Davidsson J, Agoston D, Grafman J, Risling M. 2014. Alteration in BDNF and its receptors, full-length and truncated TrkB and p75(NTR) following penetrating traumatic brain injury. Brain Research 1542:195-205.

Salas C, Broglio C, Rodriguez F. 2003. Evolution of forebrain and spatial cognition in vertebrates: Conservation across diversity. Brain Behavior and Evolution 62(2):72-82.

SchmidtKastner R, Wetmore C, Olson L. 1996. Comparative study of brain-derived neurotrophic factor messenger RNA and protein at the cellular level suggests multiple roles in hippocampus, striatum and cortex. Neuroscience 74(1):161-183.

Schober ME, Block B, Requena DF, Hale MA, Lane RH. 2012. Developmental traumatic brain injury decreased brain derived neurotrophic factor expression late after injury. Metabolic Brain Disease 27(2):167-173. 
Silhol M, Bonnichon V, Rage F, Tapia-Arancibia L. 2005. Age-related changes in brain-derived neurotrophic factor and tyrosine kinase receptor isoforms in the hippocampus and hypothalamus in male rats. Neuroscience 132(3):613-624.

Skaggs K, Goldman D, Parent JM. 2014. Excitotoxic Brain Injury in Adult Zebrafish Stimulates Neurogenesis and Long-Distance Neuronal Integration. Glia 62(12):2061-2079.

Skoglosa Y, Lewen A, Takei N, Hillered L, Lindholm D. 1999. Regulation of pituitary adenylatecyclase activating polypeptide and its receptor type 1 after traumatic brain injury: Comparison with brain-derived neurotrophic factor and the induction of neuronal cell death. Neuroscience 90(1):235-247.

Tapia-Arancibia L, Aliaga E, Silhol M, Arancibia S. 2008. New insights into brain BDNF function in normal aging and Alzheimer disease. Brain Research Reviews 59(1):201-220.

Vajn K, Plunkett JA, Tapanes-Castillo A, Oudega M. 2013. Axonal regeneration after spinal cord injury in zebrafish and mammals: differences, similarities, translation. Neuroscience Bulletin 29(4):402-410.

Vissio PG, Canepa MM, Maggese MC. 2008. Brain-derived neurotrophic factor (BDNF)-like immunoreactivity localization in the retina and brain of Cichlasomadimerus (Teleostei, Perciformes). Tissue \& Cell 40(4):261-270.

Wang Y, Cao M, Liu AQ, Di WY, Zhao F, Tian YJ, Jia JW. 2013. Changes of Inflammatory Cytokines and Neurotrophins Emphasized Their Roles in Hypoxic-Ischemic Brain Damage. International Journal of Neuroscience 123(3):191-195.

Wu HT, Lu DY, Jiang H, Xiong Y, Qu CS, Li B, Mahmood A, Zhou D, Chopp M. 2008. Simvastatin-mediated upregulation of VEGF and BDNF, activation of the PI3K/Akt pathway, and increase of neurogenesis are associated with therapeutic improvement after traumatic brain injury. Journal of Neurotrauma 25(2):130-139.

Wysokinski A. 2016. Serum levels of brain-derived neurotrophic factor (BDNF) and neurotrophin-3 (NT-3) in depressed patients with schizophrenia. Nordic Journal of Psychiatry 70(4):267-271.

Xuan WJ, Agrawal T, Huang LY, Gupta GK, Hamblin MR. 2015. Low-level laser therapy for traumatic brain injury in mice increases brain derived neurotrophic factor (BDNF) and synaptogenesis. Journal of Biophotonics 8(6):502-511.

Yang K, PerezPolo JR, Mu XS, Yan HQ, Xue JJ, Iwamoto Y, Liu SJ, Dixon CE, Hayes RL. 1996. Increased expression of brain-derived neurotrophic factor but not neurotrophin-3 mRNA in rat brain after cortical impact injury. Journal of Neuroscience Research 44(2):157-164.

Zupanc GKH, Sirbulescu RF. 2011. Adult neurogenesis and neuronal regeneration in the central nervous system of teleost fish.European Journal of Neuroscience 34(6):917-929. 
Table 1: Primary and secondary antibodies used in our study.

\begin{tabular}{|c|c|c|c|}
\hline \multicolumn{4}{|c|}{ Primary antibodies } \\
\hline Antibodies & Antibody ID & Antigen & Reference \\
\hline $\begin{array}{l}\text { Monoclonal } \\
\text { Anti-Proliferating cell } \\
\text { nuclear antigen } \\
\text { (PCNA) }\end{array}$ & $\begin{array}{c}\text { RRID } \\
\text { AB_477413 }\end{array}$ & $\begin{array}{l}\text { Rat PCNA-protein A fusion } \\
\text { protein obtained from vector } \mathrm{pC} 2 \mathrm{~T}\end{array}$ & $\begin{array}{c}\text { Clone PC10 } \\
\text { Ref MO879 } \\
\text { Dako } \\
\text { Dilution 1:100 }\end{array}$ \\
\hline $\begin{array}{l}\text { Monoclonal } \\
\text { Anti-acetylated tubulin }\end{array}$ & $\begin{array}{c}\text { RRID } \\
\text { AB_477585 }\end{array}$ & $\begin{array}{l}\text { Acetylated tubulin from the outer } \\
\text { arm of } \\
\text { Strongylocentrotuspurpuratus (sea } \\
\text { urchin) }\end{array}$ & $\begin{array}{l}\text { Clone 6-11B-1 } \\
\text { Ref T673 } \\
\text { Sigma } \\
\text { Dilution 1:100 } \\
\end{array}$ \\
\hline $\begin{array}{l}\text { Monoclonal } \\
\text { Anti-HuC/D }\end{array}$ & $\begin{array}{c}\text { RRID } \\
\text { AB_221448 }\end{array}$ & $\begin{array}{c}\text { Anti-Human } \mathrm{HuC} / \mathrm{HuD} \text { neuronal } \\
\text { protein }\end{array}$ & $\begin{array}{c}\text { Clone 16A11 } \\
\text { Ref A21271 } \\
\text { Thermo Fisher } \\
\text { Scientific } \\
\text { Dilution 1:20 }\end{array}$ \\
\hline \multicolumn{4}{|c|}{ Secondary antibodies } \\
\hline Antibodies & Antibody ID & $\begin{array}{r}\text { Reference } \\
\end{array}$ & \\
\hline $\begin{array}{l}\text { Goat anti-mouse } \\
\text { Alexa Fluor } 488\end{array}$ & $\begin{array}{c}\text { RRID } \\
\text { AB_2633275 }\end{array}$ & $\begin{array}{c}\text { A-32723 } \\
\text { Thermo Fisher Scientific } \\
\text { Dilution 1:200 }\end{array}$ & \\
\hline
\end{tabular}


A

BDNF

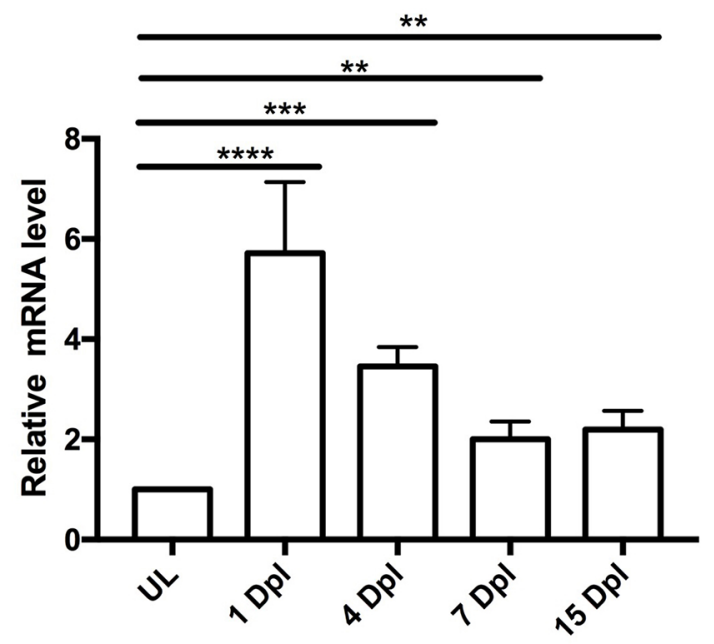

B

PCNA

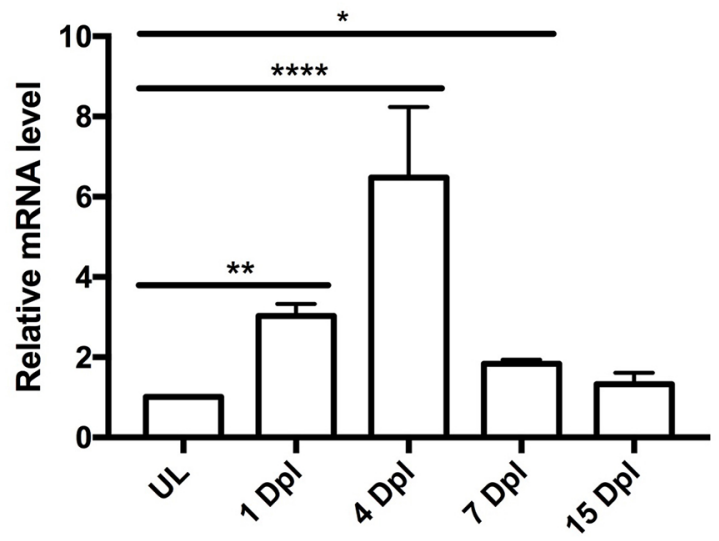



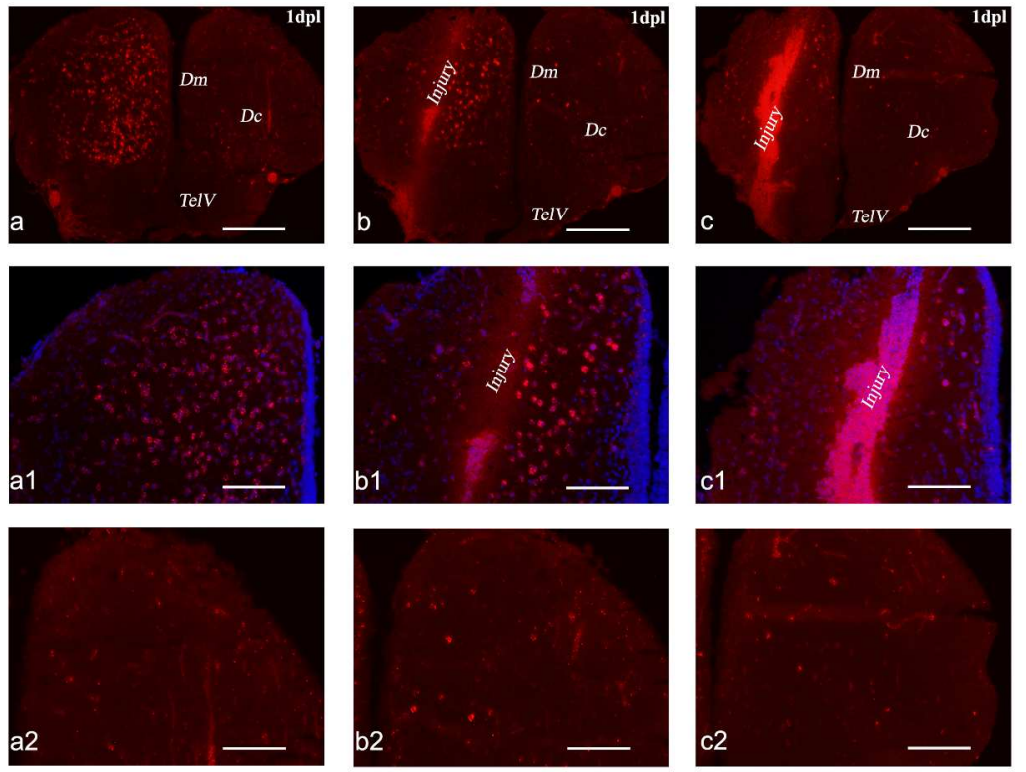

Fig. 2 BDNF mRNA expression at $1 \mathrm{dpl}$ on transversal rostro-caudal sections of injured (left side) and noninjured telencephali (right side). a-c low magnification of both telencephalic sides. a1-c1 high magnification of injured side. a2-c2 high magnification of non-injured side. In a1-c1 cell nuclei are labeled with Dapi (blue). Dm: medial zone of the dorsal telencephalon; Dc: central zone of the dorsal telencephalon; TelV: ventral telencephalon. Epifluorescence microscope, scale bar $200 \mu \mathrm{m}$ in a, b, c; $60 \mu \mathrm{m}$ in a1- c1 and a2 c2. 

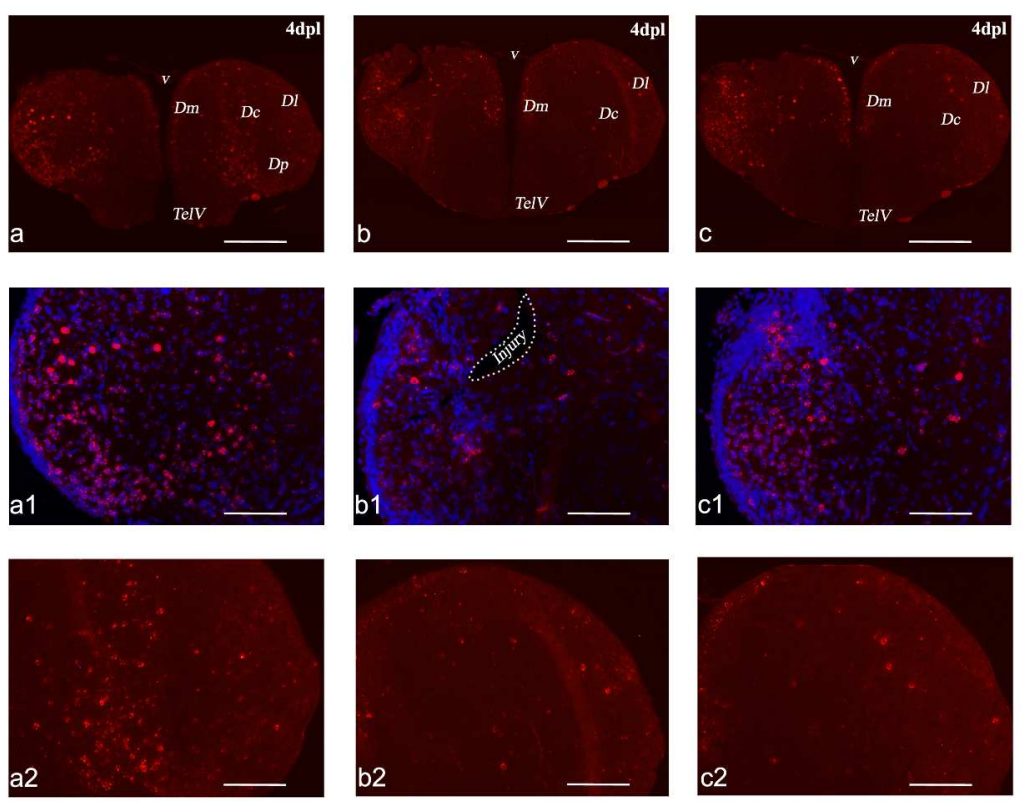

Fig. 3 BDNF mRNA expression at $4 \mathrm{dpl}$ on transversal rostro-caudal sections of injured (left side) and noninjured telencephali (right side). a-c low magnification of both telencephalic sides. a1-c1 high magnification of injured side. a2-c2 high magnification of non-injured side. In a1-c1 cell nuclei are labeled with Dapi (blue). Dm: medial zone of the dorsal telencephalon; Dc: central zone of the dorsal telencephalon; DI: lateral zone of the dorsal telencephalon; $\mathrm{Dp}$ : posterior zone of the dorsal telencephalon; TelV: ventral telencephalon; v: ventricle. Epifluorescence microscope, scale bar $=250 \mu \mathrm{m}$ in a-c; $60 \mu \mathrm{m}$ in a1- c1 and a2 $-\mathrm{c} 2$. 

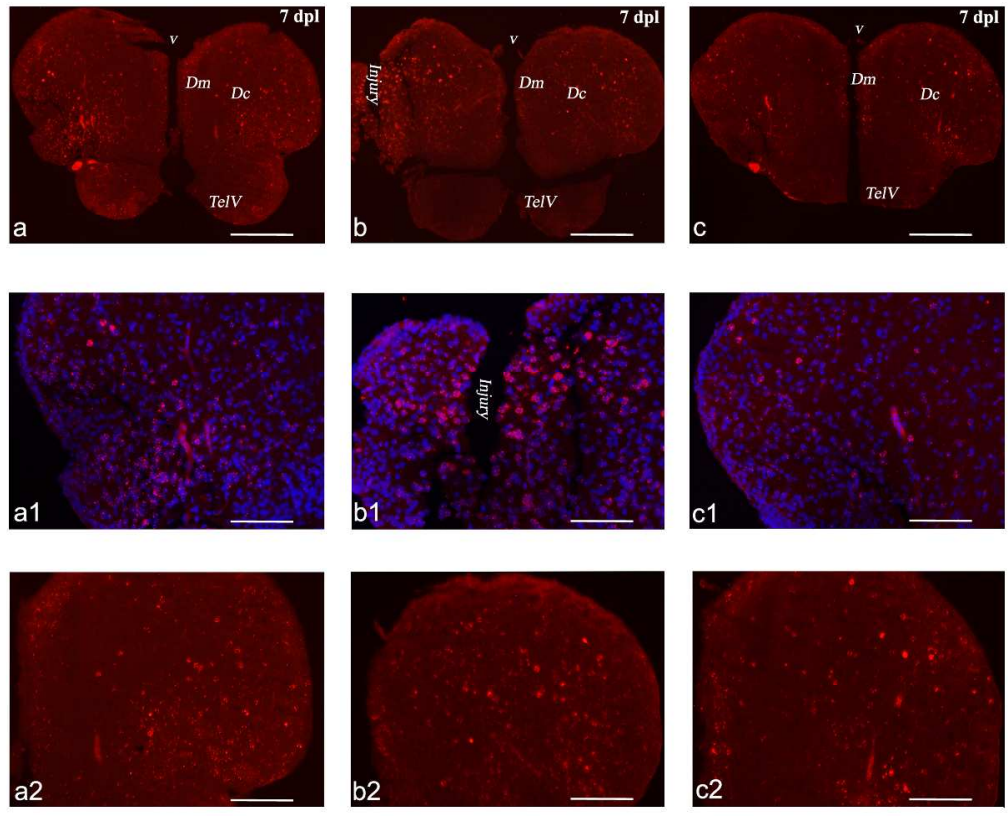

Fig. 4 BDNF mRNA expression at $7 \mathrm{dpl}$ on transversal rostro-caudal sections of injured (left side) and noninjured telencephali (right side). a-c low magnification of both telencephalic sides. a1-c1 high magnification of injured side. a2-c2 high magnification of non-injured side. In a1-c1 cell nuclei are labeled with Dapi (blue). Dm: medial zone of the dorsal telencephalon; Dc: central zone of the dorsal telencephalon; TelV: ventral telencephalon; v: ventricle. Epifluorescence microscope, scale bar $200 \mu \mathrm{m}$ in a, b, c; $60 \mu \mathrm{m}$ in a1$\mathrm{c} 1$ and $\mathrm{a} 2-\mathrm{c} 2$. 

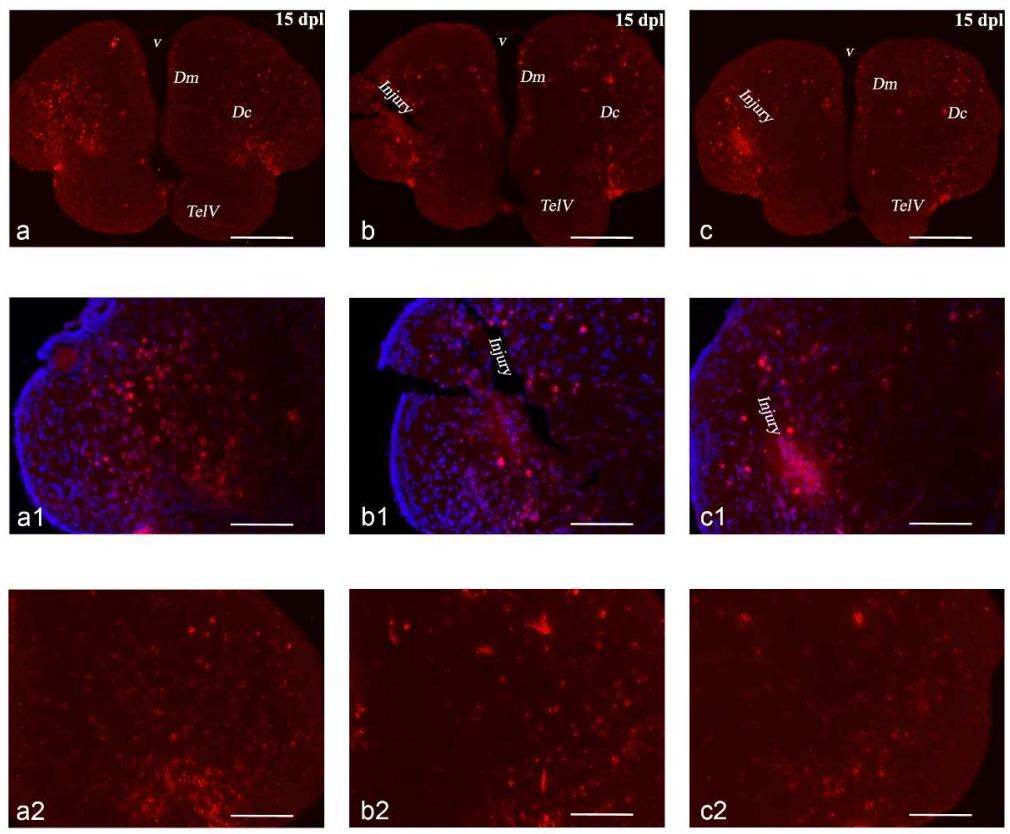

Fig. 5 BDNF mRNA expression at $15 \mathrm{dpl}$ on transversal rostro-caudal sections of injured (left side) and noninjured telencephali (right side). a-c low magnification of both telencephalic sides. a1-c1 high magnification of injured side. a2-c2 high magnification of non-injured side. In a1-c1 cell nuclei are labeled with Dapi (blue). Dm: medial zone of the dorsal telencephalon; Dc: central zone of the dorsal telencephalon; TelV: ventral telencephalon; v: ventricle. Epifluorescence microscope, scale bar $200 \mu \mathrm{m}$ in a, b, c; $60 \mu \mathrm{m}$ in a1c1 and a2 - c2.

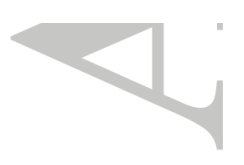


Bdnf mRNA expressing cells

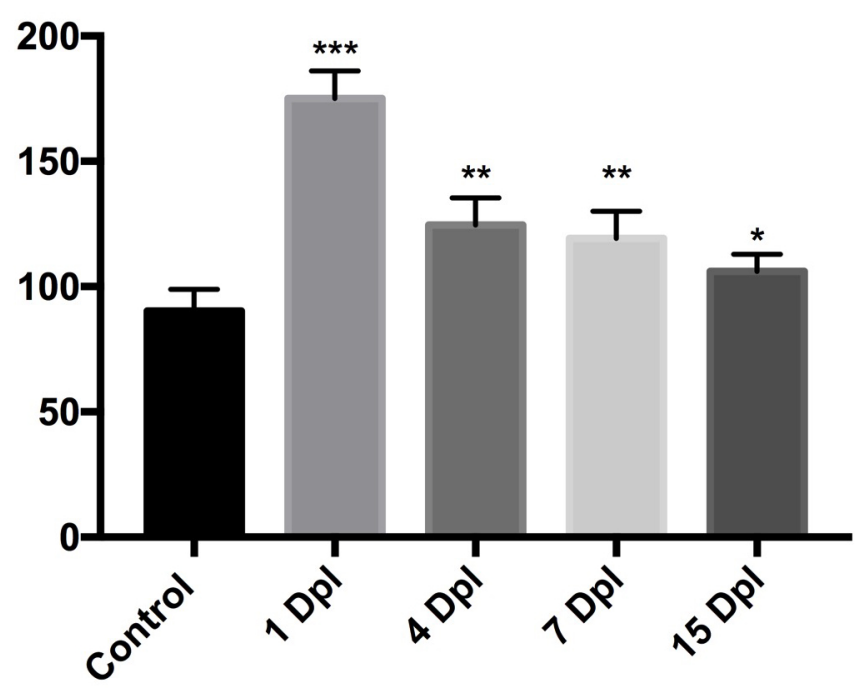




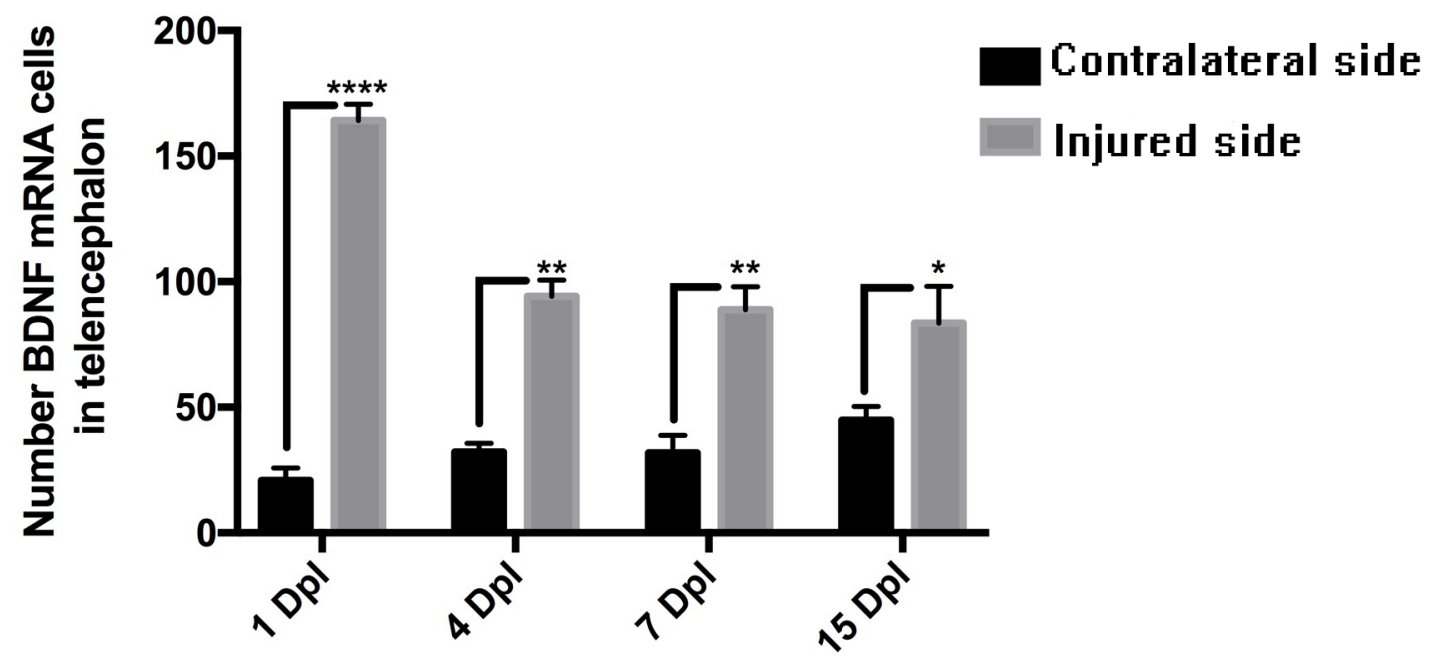



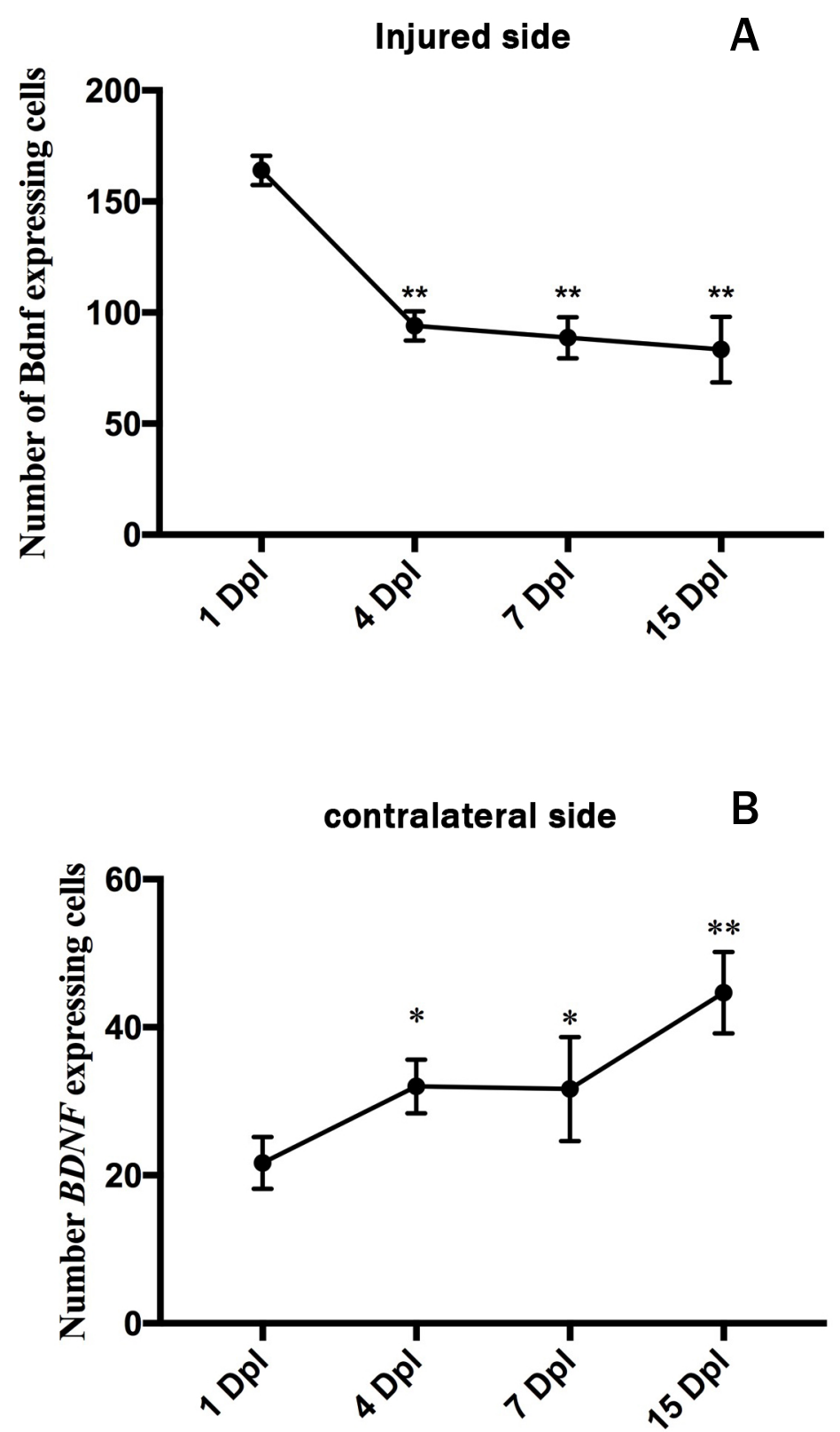

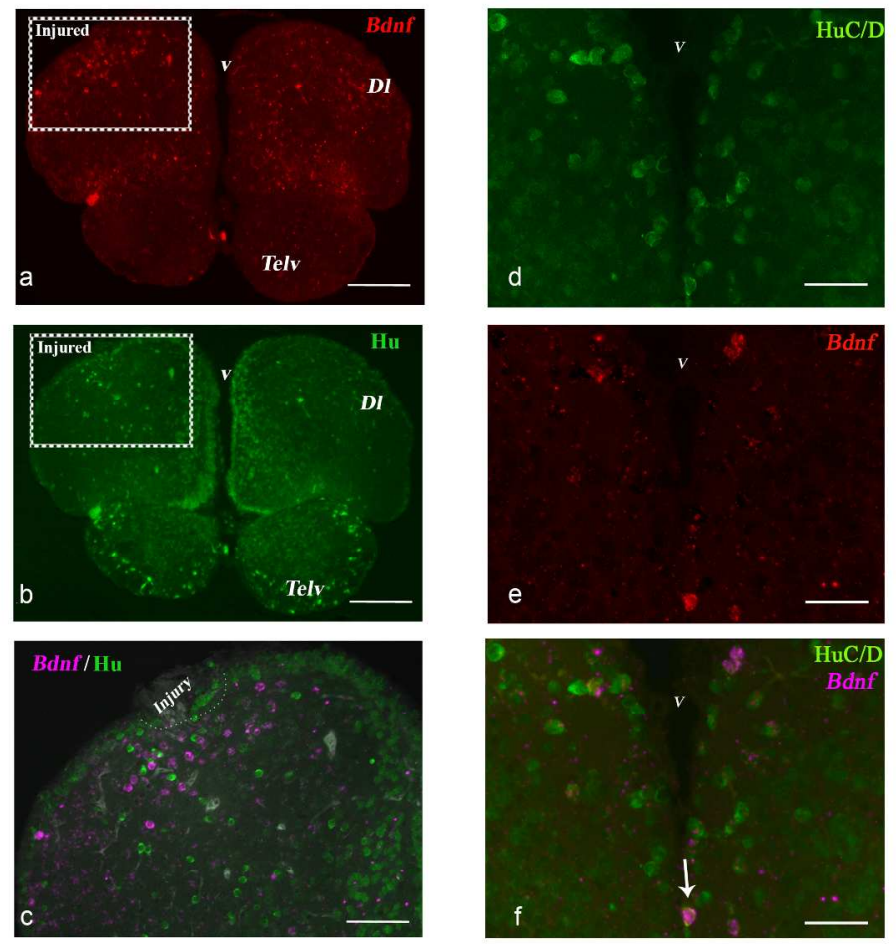

Fig. 9 Double ISH/IHC staining in injured (left side) telencephalon of $1 \mathrm{dpl}$ zebrafish showing BDNF mRNA (red) and HuC/D protein (green). $\mathrm{C}$ is high magnification of the rectangular areas showed respectively in and B. D, E. F high magnification of medial zone of telencephalon showing BDNF/HuC/D cell (arrow). In $c$ and $f$ red-green fluorescence was converted in magenta-green colors to make the figures more accessible to male readers who are red-green color blind. DI: lateral zone of the dorsal telencephalon; TelV: ventral telencephalon; v: ventricle. Epifluorescence microscope, scale bar a-b $200 \mu \mathrm{m}$; c $50 \mu \mathrm{m}$; d-f $30 \mu \mathrm{m}$.

$$
209 \times 297 \mathrm{~mm}(300 \times 300 \mathrm{DPI})
$$



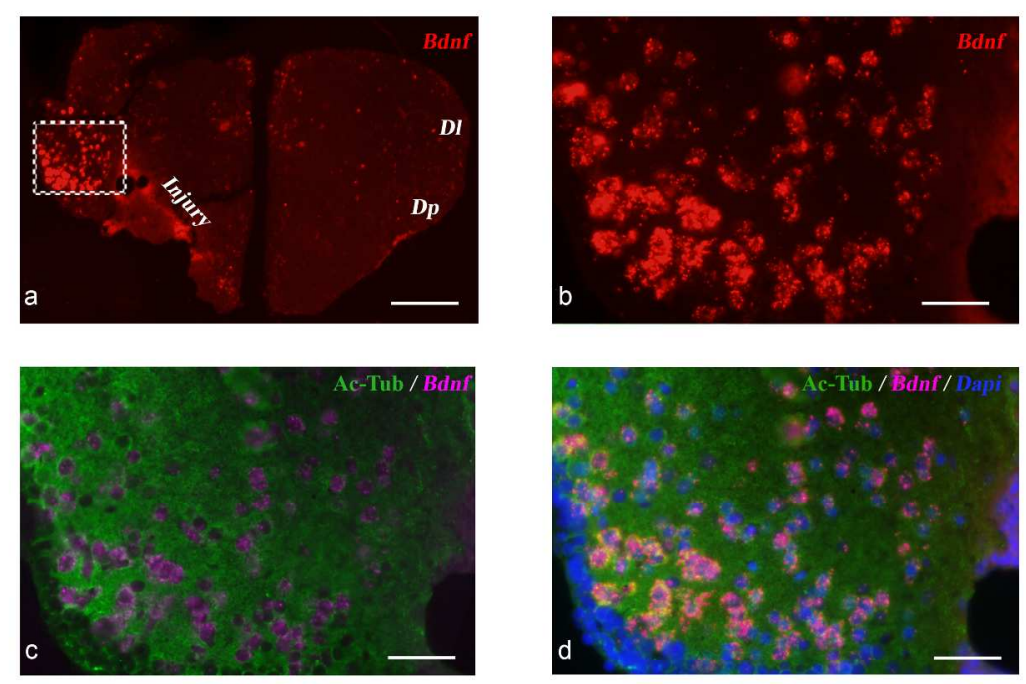

Fig. 10 Double ISH/IHC staining in injured (left side) telencephalon of $1 \mathrm{dpl}$ zebrafish showing BDNF mRNA (red) and acetylated-tubulin (green). B, c, d are magnifications of the rectangular area showed in a. In d cell nuclei are labeled in blue with DAPI. In $c$ and $d$ red-green fluorescence was converted in magenta-green colors to make the figures more accessible to male readers who are red-green color blind. DI: lateral zone of the dorsal telencephalon; Dp: posterior zone of the dorsal telencephalon. Epifluorescence microscope, scale bar: a $200 \mu \mathrm{m} ;$ b-c-d $25 \mu \mathrm{m}$ 

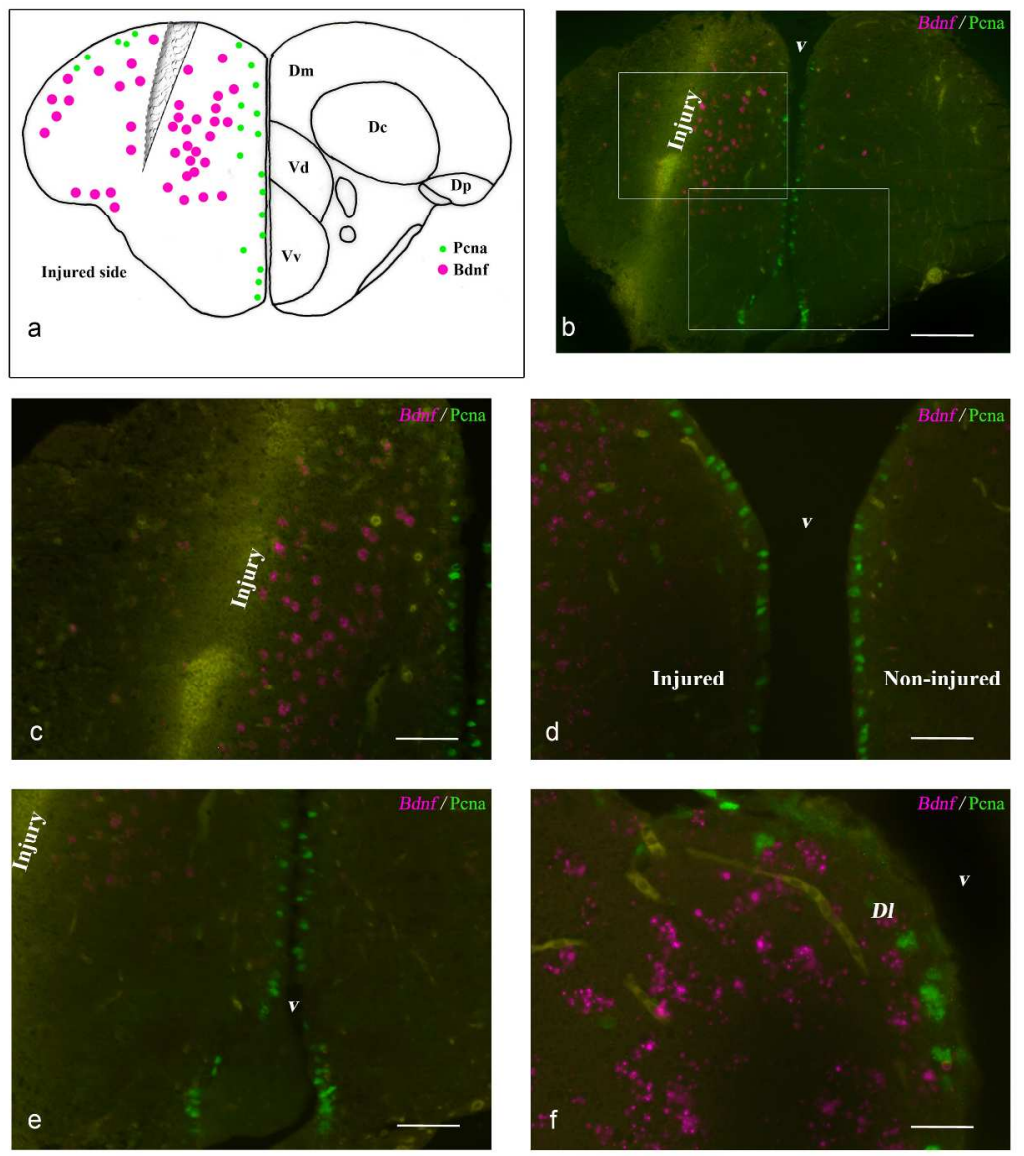

Fig. 11 Double ISH/IHC staining in injured (left side) telencephalon at $1 \mathrm{dpl}$ showing BDNF mRNA (magenta) and PCNA protein (green). (a) is a representative section of the injured telencephalon showing cells containing BDNF mRNA (magenta dots) and PCNA (green dots). At low (b), middle (c, d, f) and high (f) magnification, BDNF mRNA expressing cells were scattered in the parenchyma and PCNA positive cells were lining the telencephalic ventricle. $c$ and e are magnifications of the rectangular areas showed in $B$. Dc: central zone of the dorsal telencephalon; DI: lateral zone of the dorsal telencephalon; Dm: medial zone of the dorsal telencephalon; Dp: posterior zone of the dorsal telencephalon; v: ventricle; Vd: dorsal zone of the ventral telencephalon; Vv: ventral zone of the ventral telencephalon. Epifluorescence microscope (b-e), confocal microscope (Ffscale bar: B $200 \mu \mathrm{m}$; c-d-e $60 \mu \mathrm{m}$; f $40 \mu \mathrm{m}$ 
In zebrafish telencephalon BDNF mRNA was assessed by quantitative PCR and in situ hybridization at 1, 4, 7 and 15 days post lesion. The authors demonstrated that: a) the peak of BDNF mRNA expression was observed early after the lesion, mostly in the area surrounding the injury; b) BDNF mRNA induction was observed in mature neuronal populations.
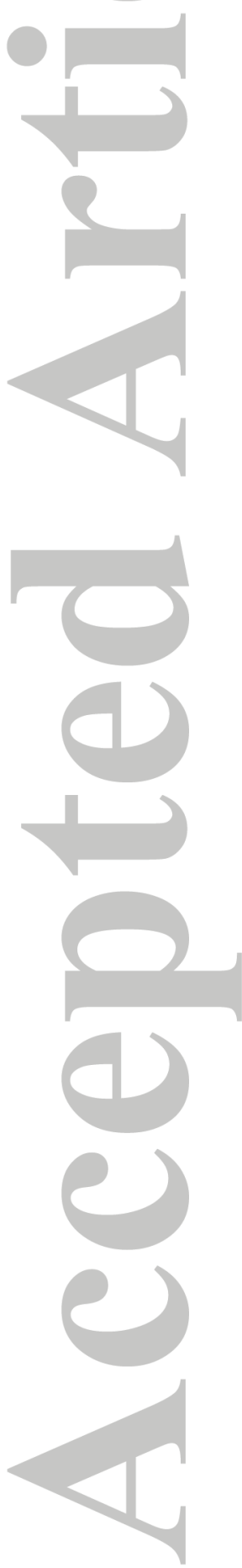

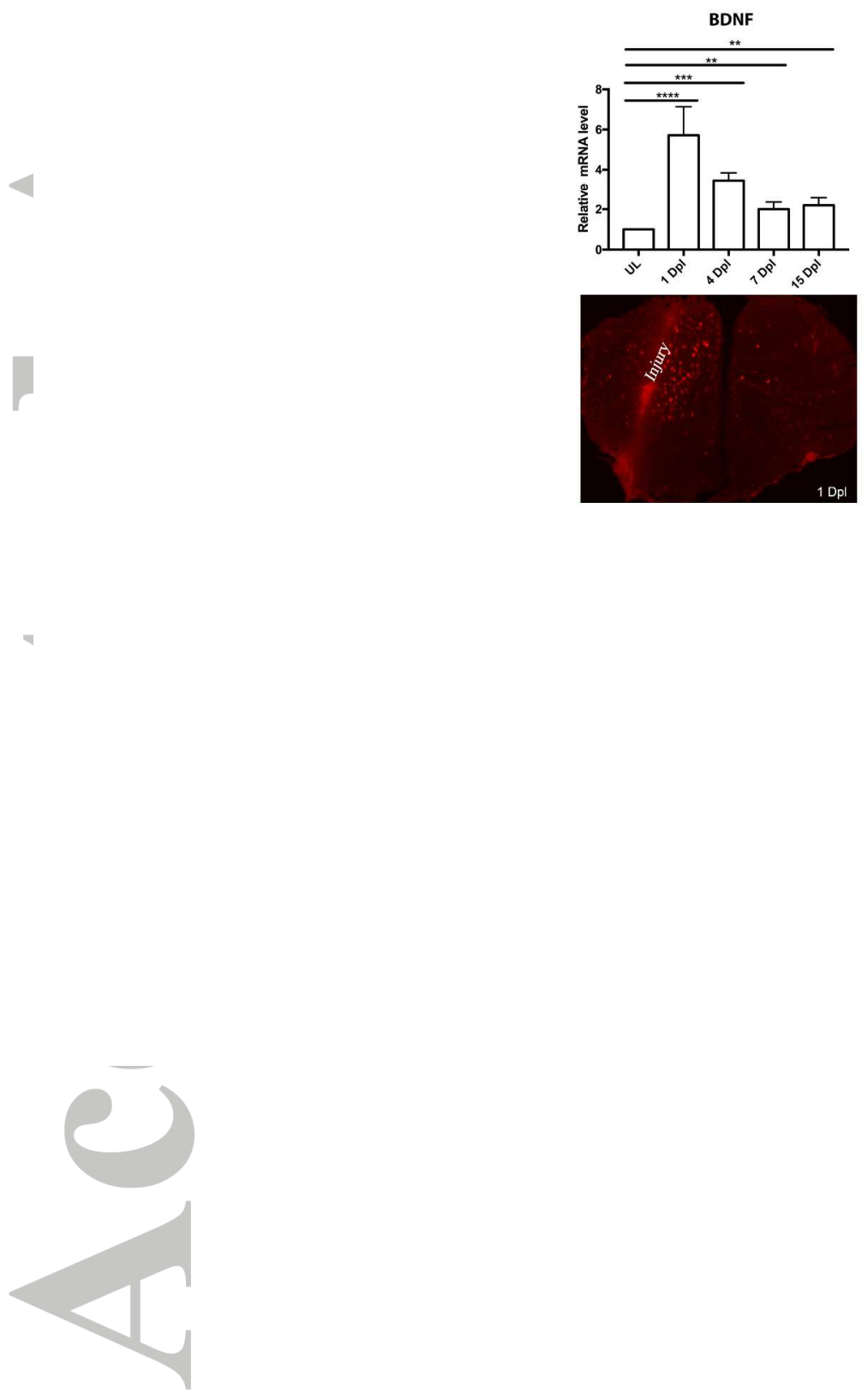